\title{
EFFICIENCY OF SNATCH TECHNIQUE IN HIGH LEVEL WEIGHTLIFTERS
}

\author{
Anatoly Shalmanov ${ }^{1}$, Vitaly Skotnikov ${ }^{1}$, Elena Lukunina ${ }^{1}$, Janis Lanka ${ }^{2}$ \\ Russian State University of Physical Education, Sport and Tourism ${ }^{1}$, Moscow, Russia \\ Latvian Academy of Sport Education ${ }^{2}$, Riga, Latvia
}

\begin{abstract}
Background. Rich theoretical and experimental evidence on the biomechanics of weightlifting exercises has currently been collected (Bauman, Gross, \& Quade, 1988; Garhammer, 1991; Gourgoulis, Aggelousis, \& Mavromatis, 2000; Isaka, Okada, \& Funato, 1996; Шалманов, Скотников, \& Панин, 2012). Most of the studies were mainly carried out in laboratory settings, with long-term treatment of the obtained data. In recent years, scientists' interest has shifted to the study and evaluation of the technical mastery of athletes in the setting of the highest level competition, in the extreme conditions of sport fight. This was facilitated by the development of specialized hardware and program sets (Шалманов \& Скотников, 2013; Шалманов, Скотников \& Ланка, 2013), opening the possibility for biomechanical control of athletes technical and speed-strength fitness both during the technical training process and competition. One of the ways of evaluating the effectiveness of techniques is based on the idea of using motor capacity by an athlete, which is called efficiency of realization.

Methods. To register the trajectory of the bar and calculate kinematic and dynamic parameters of its movement a specialized hardware-program complex (APC) has been developed. In the APC, a photo-video camera "Canon" is included; a marker is fixed on the end of the bar as well as a computer with software. Recording was carried out during major competitions (Cup of Russia, the Russian Championship, and the XXVII World Summer Universiade) in 2012-2014. The total number of athletes surveyed was 331 people (184 men, 147 women). The paper presents the results obtained in the snatch in men.

Results. The regularities in the change of kinematic and dynamic bar movement parameter with an increase in weight category and sport result were determined. The main indicator determining sports result in a classic snatch was the absolute maximum power developed by the athlete during acceleration of the bar in the final phase of its lifting: $r=.75, p<.001$. The indicator of absolute power is the most informative to assess the level of athlete speedstrength fitness, realized due to the efficiency of sports technique and prediction of sports result.

Conclusions. The regression equation between the result in the snatch and the maximum absolute power in the final acceleration of the bar give a possibility to evaluate the technique of the effectiveness of each athlete: if it is better or worse than the average one and to what extent. This analysis gave one more possibility - to compare the set up performance with the performance that the athlete, taking into account their level of physical conditioning (maximal power), would achieve if they improve their technique.
\end{abstract}

Keywords: biomechanical control, technical and physical fitness, technique realization effectiveness.

\section{INTRODUCTION}

$\mathrm{T}$ The effectiveness of management of training process, especially in highly qualified athletes, depends on the timeliness and completeness of the information about the condition of the athlete, the quality of their techniques, and the comparison of these data with the amount and characteristics of the training load. The main objective of biomechanical monitoring is to evaluate the motor capacities and technical skills of athletes using instrumental means. At the forefront here extends the operational and current monitoring, which is based on the testing 
of athlete motor abilities and the quality of the execution of any given exercise immediately after the completion of the motor exercise.

Despite the fact that numerous measuring systems are available currently (Шалманов, 2002), not all of them can be used for operational and current control. The possibilities of their application in competitive conditions are limited. The main difficulty lies in the speed of obtaining the necessary information, and, in addition, the testing procedure should not interfere with the natural course of the training process and athlete activity. One solution to this problem is the development of specialized hardware-software complexes and their introduction into the training process.

No less important is finding ways to assess athlete technical mastery. One approach to technology assessment is based on the idea of using athlete potential motor abilities, such as speed and strength. In its implementation athlete must perform two exercises. The first exercise is to assess the level of technical mastery, and the second exercise - to measure athlete's speed and strength. The technique of the execution of the second exercise should be extremely simple; the result in it should depend only on the speed and strength abilities of the athlete. Then the regression equation between the results of two exercises is calculated, and with the help of this equation the efficiency of the techniques realized is determined (regression residuals). This method was proposed by Zatsiorsky and implemented by his co-workers
(Lanka \& Shalmanov, 2004; Lanka, Konrad, \& Shalmanov, 2005; Ланка, \& Шалманов, 1982).

The aim of the research was the development of the methodology for biomechanical control of athlete speed - strength fitness and the assessment of the efficiency of athlete's technique.

\section{METHODS}

To register the trajectory of the bar, kinematic and dynamic parameters of its motion were calculated and biomechanical analysis of the athlete activity was performed as well as a methodology that could be used both in the training process, and in the conditions of competition was developed (Шалманов et al., 2012; Шалманов \& Скотников, 2013). The methodology comprises a photo-camera "Canon" marker attached to the end of the neck of the bar and a computer with software. The camera is set to the side of the platform at a distance of $5.5 \mathrm{~m}$ from the marker at a height of $1.5 \mathrm{~m}$. The optical axis is perpendicular to the camera shooting. The frequency of shooting is 50 shots per second. Recording was carried out during major competitions (Cup of Russia, the Russian Championship and the XXVII World Summer Universiade) in 2012-2014. More than 1,000 attempts in the snatch and clean and jerk in all weight categories for men and women were recorded. For further processing the best attempts of athletes having shown the results relevant to the regulations of master of sports according to

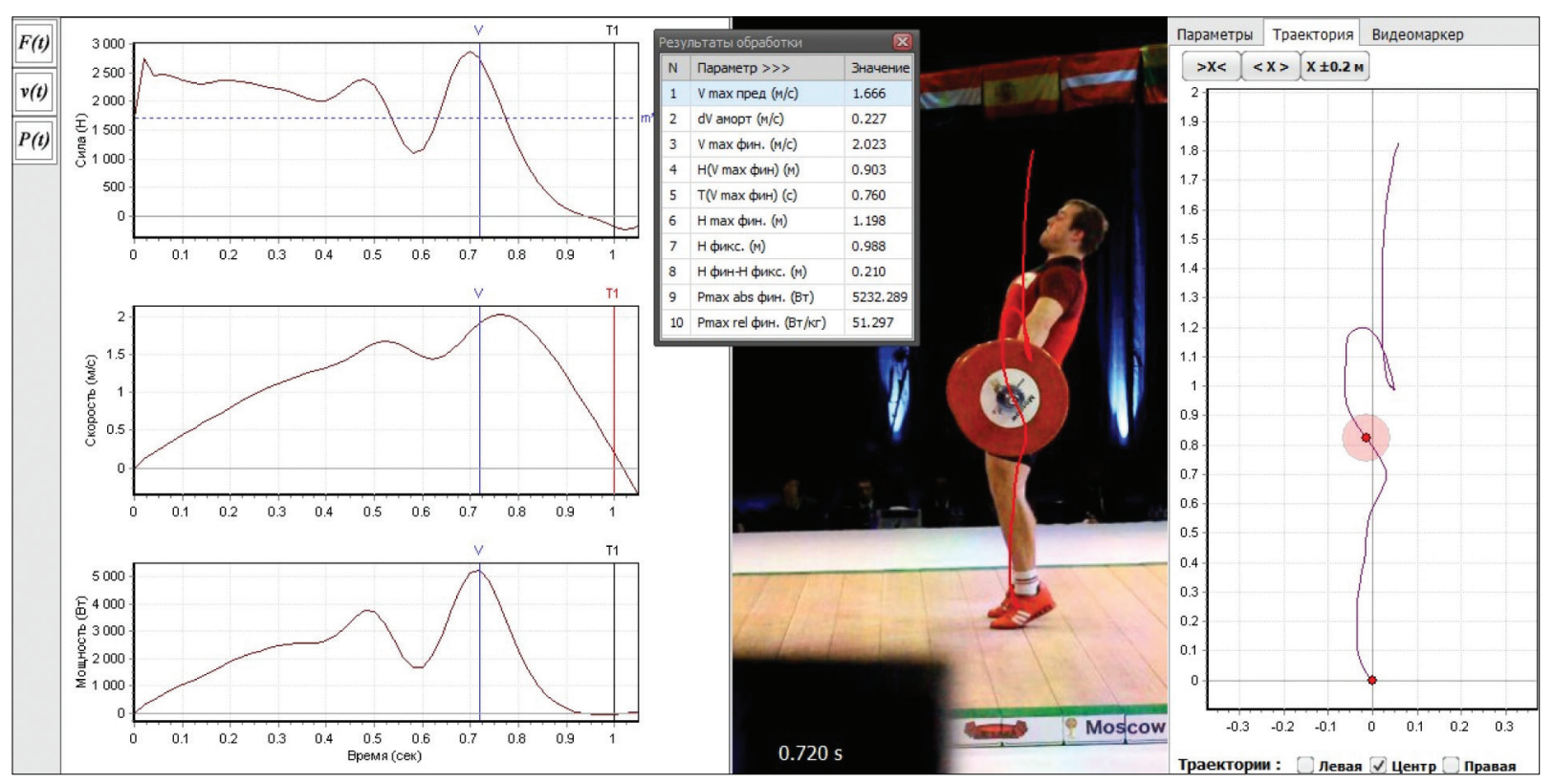

Figure 1. Kinematic and dynamic characteristics of the movement, position of the athlete at the moment of maximum power in the final acceleration, and bar trajectory in the snatch 
the classification adopted in Russia were chosen. The total number of athletes researched was 331 people (184 men, 147 women). The paper presents the research results in the snatch in men.

The process of data collection and processing for one attempt takes less than one minute. The program displays the graphs of the change of vertical force applied to the bar, speed and power, the trajectory of the bar and the position of the athlete.

In processing the raw data, the program automatically finds the value of the selected kinematic and dynamic parameters of movement. In addition, the program provides an opportunity to measure the current value of movement characteristics listed after every $0.02 \mathrm{~s}$ from the beginning of raising the bar until its fixation at the end of the exercise.

\section{RESULTS}

Characteristics of the athletes and the mean values of the basic kinematic and dynamic parameters are presented in Table 1.
The data show that with increasing weight category, overall weight and height data of the athletes increased not only sport result, but it also changed most of the kinematic parameters of the motion of the bar: maximum speed of the bar in the preliminary acceleration, the height of the implement in different movement moments, the time of reaching maximum speed in the final acceleration increased.

Analysis of correlations between these parameters of bar movement and the results in the snatch showed that the main indicator determining sports result was the absolute maximum power during acceleration of the bar in the final phase of its lifting: $r=.75 . p<.001$ (Figure 2).

This means that approximately $50 \%$ of the result in snatch is determined by the power developed by the athletes during the acceleration of the bar. The remaining $50 \%$ are caused by other factors, one of which is the technical mastery of the athlete.

Taking the correlation between the result in the snatch and the maximum power as the basis, we tried to evaluate the effectiveness of the technique realized by the athletes, using the method of the

Table 1. Mean values and standard deviations of the parameters of motion of the bar in the snatch in athletes of different weight categories

\begin{tabular}{|c|c|c|c|c|c|c|c|c|c|}
\hline \multirow{2}{*}{ No. } & \multirow{2}{*}{ Indicator } & \multicolumn{8}{|c|}{ Weight categories (kg) } \\
\hline & & $\begin{array}{c}56 \\
n=13\end{array}$ & $\begin{array}{c}62 \\
n=17\end{array}$ & $\begin{array}{c}69 \\
n=16\end{array}$ & $\begin{array}{c}77 \\
n=\mathbf{3 0}\end{array}$ & $\begin{array}{c}85 \\
n=25\end{array}$ & $\begin{array}{c}94 \\
n=31\end{array}$ & $\begin{array}{c}105 \\
n=26\end{array}$ & $\begin{array}{c}+105 \\
n=26\end{array}$ \\
\hline 1. & Body height $(m)$ & $\begin{array}{c}1.59 \\
\pm 0.05\end{array}$ & $\begin{array}{c}1.60 \\
\pm 0.04\end{array}$ & $\begin{array}{c}1.65 \\
\pm 0.03\end{array}$ & $\begin{array}{c}1.72 \\
\pm 0.04\end{array}$ & $\begin{array}{c}1.72 \\
\pm 0.04\end{array}$ & $\begin{array}{c}1.77 \\
\pm 0.04\end{array}$ & $\begin{array}{c}1.81 \\
\pm 0.04\end{array}$ & $\begin{array}{r}1.85 \\
\pm 0.05\end{array}$ \\
\hline 2. & Body weight (kg) & $\begin{array}{c}55.7 \\
\pm 027\end{array}$ & $\begin{array}{c}61.1 \\
\pm 1.76\end{array}$ & $\begin{array}{c}68.3 \\
\pm 0.88\end{array}$ & $\begin{array}{c}76.1 \\
\pm 0.92\end{array}$ & $\begin{array}{c}84.3 \\
\pm 0.14\end{array}$ & $\begin{array}{l}92.8 \\
\pm 1.4\end{array}$ & $\begin{array}{l}103.1 \\
\pm 2.0\end{array}$ & $\begin{array}{r}133.3 \\
\pm 17.0\end{array}$ \\
\hline 3. & Result in the snatch $(\mathrm{kg})$ & $\begin{array}{l}101.2 \\
\pm 8.3\end{array}$ & $\begin{array}{r}118.6 \\
\pm 11.6\end{array}$ & $\begin{array}{l}137.1 \\
\pm 7.7\end{array}$ & $\begin{array}{c}139.7 \\
\pm 12.4\end{array}$ & $\begin{array}{l}150.3 \\
\pm 12.4\end{array}$ & $\begin{array}{c}161.3 \\
12.6\end{array}$ & $\begin{array}{r}169.4 \\
\pm 15.1\end{array}$ & $\begin{array}{r}178.7 \\
\pm 18.4\end{array}$ \\
\hline 4. & $\begin{array}{l}\text { Maximum speed in the first pull, } \\
V_{l}(\mathrm{~m} / \mathrm{s})\end{array}$ & $\begin{array}{l}1.25 \\
\pm 0.16\end{array}$ & $\begin{array}{r}1.15 \\
\pm 0.19\end{array}$ & $\begin{aligned} & 1.21 \\
\pm & 0.20\end{aligned}$ & $\begin{array}{r}1.35 \\
\pm 0.18\end{array}$ & $\begin{array}{c}1.34 \\
\pm 0.16\end{array}$ & $\begin{array}{r}1.33 \\
\pm 0.17\end{array}$ & $\begin{array}{r}1.40 \\
\pm 0.18\end{array}$ & $\begin{array}{r}1.43 \\
\pm 0.17\end{array}$ \\
\hline 5. & $\begin{array}{l}\text { Speed reduction in amortization } \\
\text { phase, } \Delta V(\mathrm{~m} / \mathrm{s})\end{array}$ & $\begin{array}{c}0.08 \\
\pm 0.17\end{array}$ & $\begin{array}{c}0.01 \\
\pm 0.04\end{array}$ & $\begin{array}{r}0.05 \\
\pm 0.06\end{array}$ & $\begin{array}{c}0.13 \\
\pm 0.17\end{array}$ & $\begin{array}{c}0.08 \\
\pm 0.09\end{array}$ & $\begin{array}{c}0.14 \\
\pm 0.13\end{array}$ & $\begin{array}{c}0.11 \\
\pm 0.12\end{array}$ & $\begin{array}{c}0.11 \\
\pm 0.11\end{array}$ \\
\hline 6. & $\begin{array}{l}\text { Maximum speed in the second pull, } \\
\operatorname{Vmax}(\mathrm{m} / \mathrm{s})\end{array}$ & $\begin{array}{r}1.80 \\
\pm 0.13\end{array}$ & $\begin{array}{r}1.85 \\
\pm 0.12 \\
\end{array}$ & $\begin{array}{r}1.84 \\
\pm 0.12 \\
\end{array}$ & $\begin{array}{r}1.82 \\
\pm 0.20\end{array}$ & $\begin{array}{r}1.82 \\
\pm 0.13 \\
\end{array}$ & $\begin{array}{c}1.81 \\
\pm 0.14 \\
\end{array}$ & $\begin{array}{r}1.87 \\
\pm 0.17 \\
\end{array}$ & $\begin{array}{c}1.86 \\
\pm 0.15 \\
\end{array}$ \\
\hline 7. & Height at Vmax, $H V \max (m)$ & $\begin{array}{c}0.70 \\
\pm 0.04\end{array}$ & $\begin{array}{c}0.71 \\
\pm 0.06\end{array}$ & $\begin{array}{c}0.73 \\
\pm 0.04\end{array}$ & $\begin{array}{c}0.75 \\
\pm 0.07\end{array}$ & $\begin{array}{c}0.77 \\
\pm 0.06\end{array}$ & $\begin{array}{c}0.77 \\
\pm 0.06\end{array}$ & $\begin{array}{c}0.82 \\
\pm 0.08\end{array}$ & $\begin{array}{c}0.88 \\
\pm 0.07\end{array}$ \\
\hline 8. & Time to Vmax, $T V \max (s)$ & $\begin{array}{c}077 \\
\pm 0.08 \\
\end{array}$ & $\begin{array}{c}0.73 \\
\pm 0.06 \\
\end{array}$ & $\begin{array}{c}0.78 \\
\pm 0.07 \\
\end{array}$ & $\begin{array}{c}0.74 \\
\pm 0.05 \\
\end{array}$ & $\begin{array}{c}0.77 \\
\pm 0.05 \\
\end{array}$ & $\begin{array}{c}0.79 \\
\pm 0.07 \\
\end{array}$ & $\begin{array}{c}1.10 \\
\pm 0.07 \\
\end{array}$ & $\begin{array}{c}0.84 \\
\pm 0.07 \\
\end{array}$ \\
\hline 9. & Maximum height, $\operatorname{Hmax}(m)$ & $\begin{array}{c}0.95 \\
\pm 0.04\end{array}$ & $\begin{array}{c}0.96 \\
\pm 0.07\end{array}$ & $\begin{array}{c}0.98 \\
\pm 0.05\end{array}$ & $\begin{array}{c}1.01 \\
\pm 0.09\end{array}$ & $\begin{array}{c}1.02 \\
\pm 0.07 \\
\end{array}$ & $\begin{array}{c}1.03 \\
\pm 0.08 \\
\end{array}$ & $\begin{array}{c}0.93 \\
\pm 0.03 \\
\end{array}$ & $\begin{array}{c}1.15 \\
\pm 0.09 \\
\end{array}$ \\
\hline 10. & $\begin{array}{l}\text { The height at the time of fixation, } \\
\text { Hfix }(\mathrm{m})\end{array}$ & $\begin{array}{r}0.79 \\
\pm 0.04\end{array}$ & $\begin{array}{r}0.80 \\
\pm 0.07\end{array}$ & $\begin{array}{c}0.81 \\
\pm 0.05\end{array}$ & $\begin{array}{r}0.85 \\
\pm 0.08\end{array}$ & $\begin{array}{r}0.88 \\
\pm 0.06\end{array}$ & $\begin{array}{r}0.86 \\
\pm 0.07 \\
\end{array}$ & $\begin{array}{r}0.94 \\
\pm 0.04\end{array}$ & $\begin{array}{r}0.98 \\
\pm 0.07 \\
\end{array}$ \\
\hline 11. & The difference, (Hmax-Hfix) (m) & $\begin{array}{c}0.16 \\
\pm 0.04\end{array}$ & $\begin{array}{c}0.16 \\
\pm 0.04\end{array}$ & $\begin{array}{c}0.18 \\
\pm 0.05\end{array}$ & $\begin{array}{c}0.16 \\
\pm 0.04\end{array}$ & $\begin{array}{c}0.14 \\
\pm 0.05\end{array}$ & $\begin{array}{c}0.17 \\
\pm 0.04\end{array}$ & $\begin{array}{c}0.17 \\
\pm 0.04\end{array}$ & $\begin{array}{c}0.21 \\
\pm 0.19\end{array}$ \\
\hline 12. & $\begin{array}{l}\text { Maximum absolute power, Pabs } \\
(W)\end{array}$ & $\begin{array}{l}2644 \\
\pm 523 \\
\end{array}$ & $\begin{array}{l}3063 \\
\pm 526 \\
\end{array}$ & $\begin{array}{l}3695 \\
\pm 587 \\
\end{array}$ & $\begin{array}{r}3619 \\
\pm 762 \\
\end{array}$ & $\begin{array}{l}3912 \\
\pm 626\end{array}$ & $\begin{array}{l}4243 \\
\pm 853\end{array}$ & $\begin{array}{l}4529 \\
\pm 898 \\
\end{array}$ & $\begin{array}{r}4740 \\
\pm 1096 \\
\end{array}$ \\
\hline 13. & $\begin{array}{l}\text { Maximum relative power, Prel } \\
(\mathrm{W} / \mathrm{kg})\end{array}$ & $\begin{array}{l}47.5 \\
\pm 9.4\end{array}$ & $\begin{array}{l}50.1 \\
\pm 8.5\end{array}$ & $\begin{array}{l}54.1 \\
\pm 8.6\end{array}$ & $\begin{array}{l}47.7 \\
\pm 10.0\end{array}$ & $\begin{array}{l}46.3 \\
\pm 7.3\end{array}$ & $\begin{array}{l}45.7 \\
\pm 8.9\end{array}$ & $\begin{array}{l}43.9 \\
\pm 8.8\end{array}$ & $\begin{array}{l}35.7 \\
\pm 7.7\end{array}$ \\
\hline
\end{tabular}




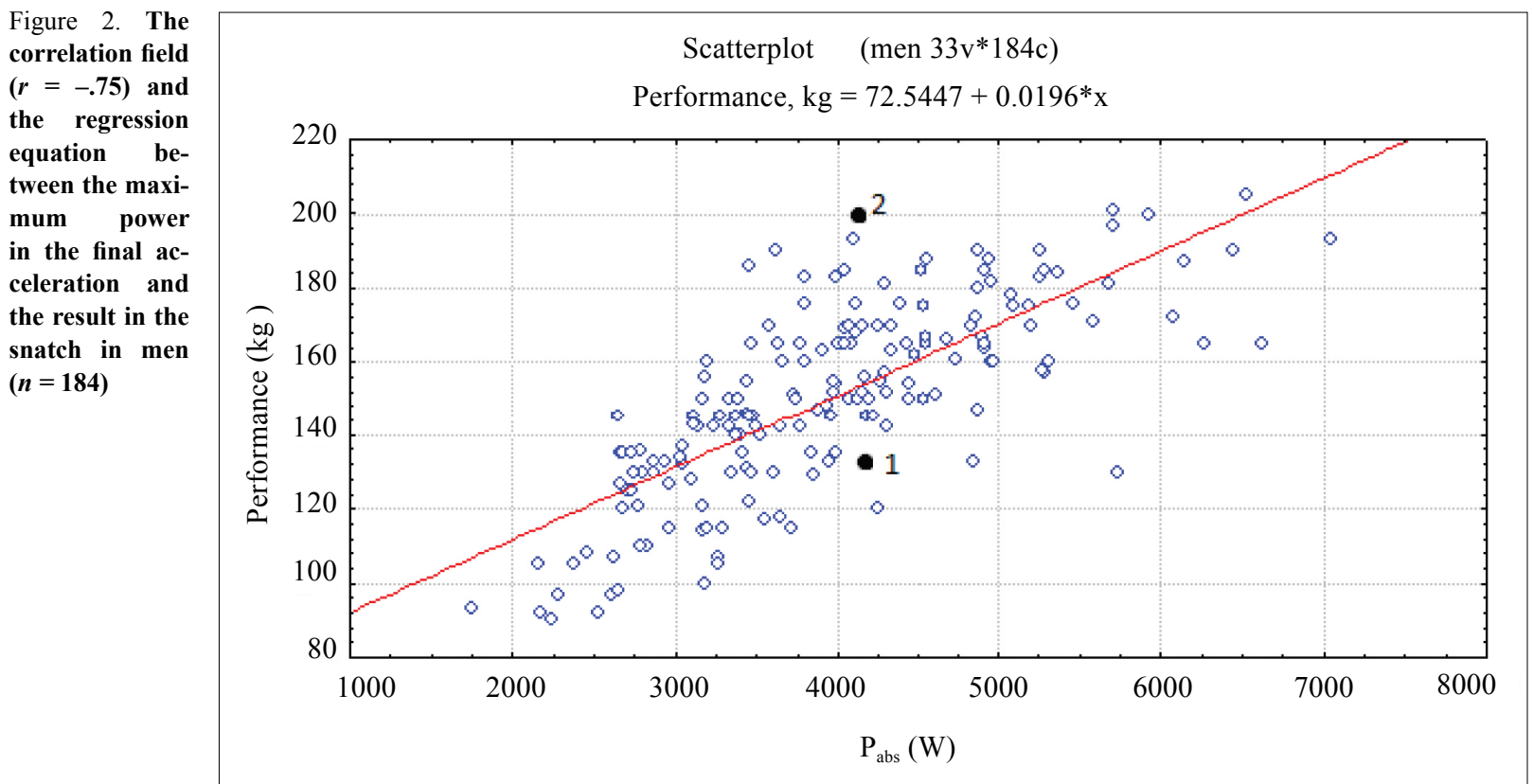

regression residuals. Traditionally this happens by comparing the athlete's results in the movement, which he or she specializes in, with the results of the execution of a movement, which is simpler to execute, but the execution of which requires that same physical characteristics.

Unlike the approach described above, in this research both athlete's technique and motor capacity were assessed in the same exercise, i.e. during the execution of the exercise in the conditions of competition. Regression equation between the results in the snatch with indicators of the maximum power that athletes develop during the acceleration of the implement was calculated:

$$
Y=72.5447+0.0196 \cdot P,
$$

where $Y$-sports performance and $P$ - the maximum absolute power.

In this case, the power is considered as an indicator of speed - strength capabilities of the athlete. Indication of athletes technical mastery is the efficiency of the techniques that is the difference between the result in the snatch, shown in competition and the average result in this exercise, calculated from the regression equation. If the difference is positive, the technique is better than average, and if negative, then it is, respectively, worse than average. The greater the difference in absolute value, the higher or lower than average is the effectiveness of the technique.

Points located above the regression line, correspond to those of the athletes with higher efficiency of the realized techniques of the performance of the exercise regardless of the result shown. The points located below the regression line, correspond to those of athletes with lower efficiency of the techniques. For example, two athletes have maximum power in the final acceleration close to 4100 watts. One athlete showed the result of $135 \mathrm{~kg}$, and the other with the same power raised the bar weighing $200 \mathrm{~kg}$. Based on athlete regression equation, athletes developing maximum power of 4100 watts on average should show the result in the snatch equal to $152 \mathrm{~kg}$. It can be assumed that athletes lifting more weight with the same amount of power show a more effective technique of the execution of the exercise. Thus, in this case, the coefficient of efficiency (CE) of the techniques in the first athlete is $-18 \mathrm{~kg}$ (the technique is worse than average), while in the second athlete it is $+47 \mathrm{~kg}$ (the technique is much better than average). Let us consider another example. In order to raise the barbell weighting 160 $\mathrm{kg}$, one athlete has develops power of 3250 watts, the other almost twice as much. The given example demonstrates the basic idea of the realization of the technique criteria: effectiveness of the technique can be assessed by comparing athlete's actual result with his or her achievement, which can be predicted taking his or her physical fitness as the basis. The difference between actual and predicted result is the measure of the effectiveness of the athlete's technique.

Table 2 shows correlation coefficients between the results in the snatch $\left(r_{1}\right)$, the coefficient of the realized efficiency of the techniques in the snatch $\left(r_{2}\right)$, some parameters of bar movement. 
Table 2. Correlation coefficients of some parameters of movement of the bar with the result in the snatch $\left(r_{1}\right)$ and the coefficient of the realized efficiency of the technique $\left(r_{2}\right)$

\begin{tabular}{|c|l|c|c|}
\hline No. & \multicolumn{1}{|c|}{ Indicator } & $\mathbf{r}_{1}$ & $\mathbf{r}_{2}$ \\
\hline 1 & Maximum speed in the final acceleration $-V_{\max }$ & .05 & -.56 \\
\hline 2 & Maximum of the height of the lift $-H_{\max }$ & -.04 & -.35 \\
\hline 3 & Relative height at the time of fixation $-H_{f x}$ & .07 & -.25 \\
\hline 4 & $\begin{array}{l}\text { Maximum relative power in the final } \\
\text { acceleration }-P_{r e l}\end{array}$ & -.13 & -.65 \\
\hline
\end{tabular}

It can be seen that the maximum speed of the bar in the final acceleration, maximum relative height and the height of bar fixation significantly $(p<$ $.05)$ negatively correlates with the coefficient of the efficiency of the snatch techniques, whereas these figures do not significantly correlate with the result. This fact suggests that more technical athletes raise maximum for themselves weights at lower height, have lower "sit", accelerate the implement to less maximum speed (Figure 3), and develop smaller relative power (Figure 4), which is logical.

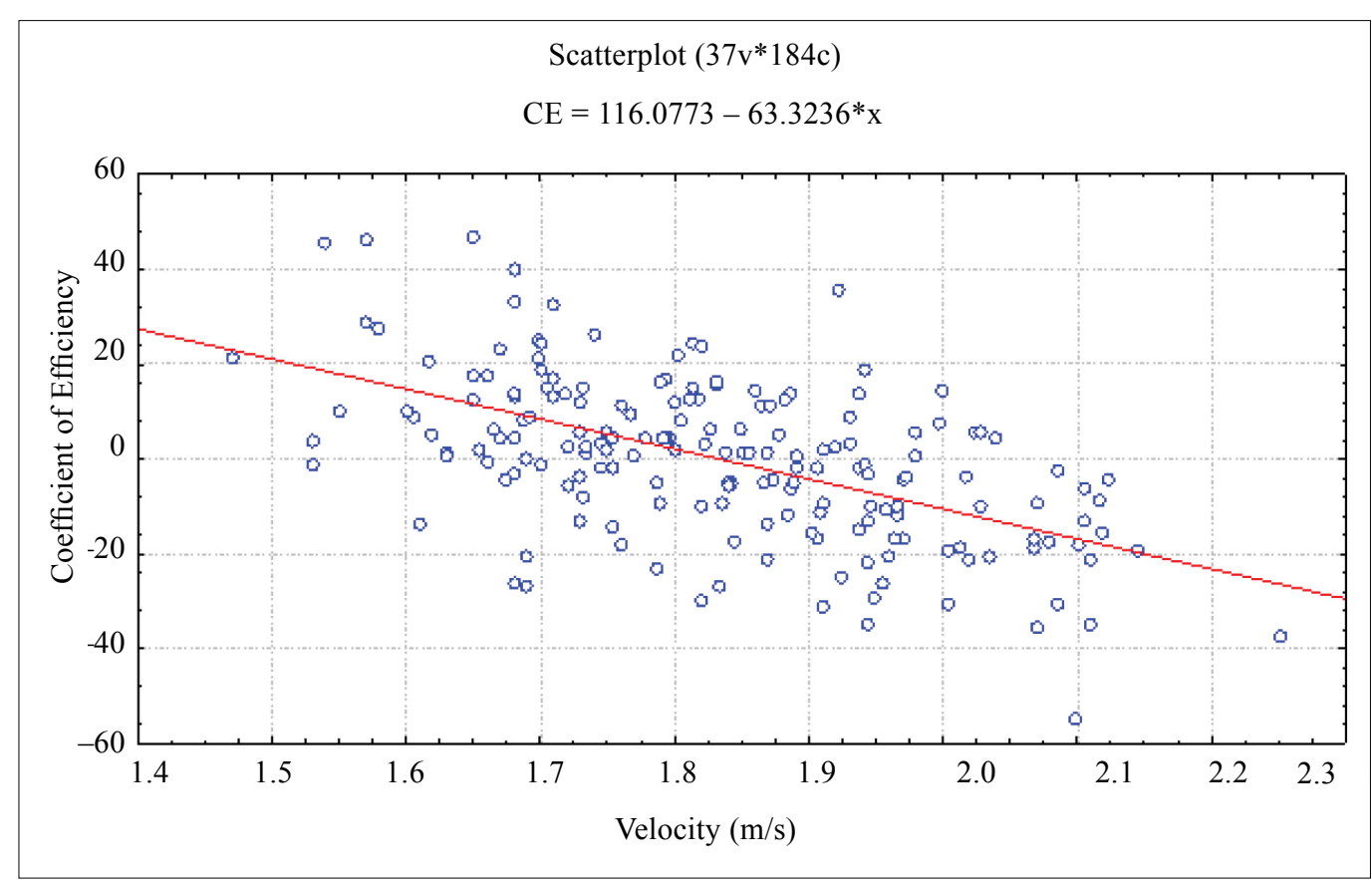

Figure 3. The correlation field $(r=$ -.56) and the regression equation between the maximum of the speed in the final acceleration and the coefficient of the efficiency of the techniques in the snatch in men $(n=184)$

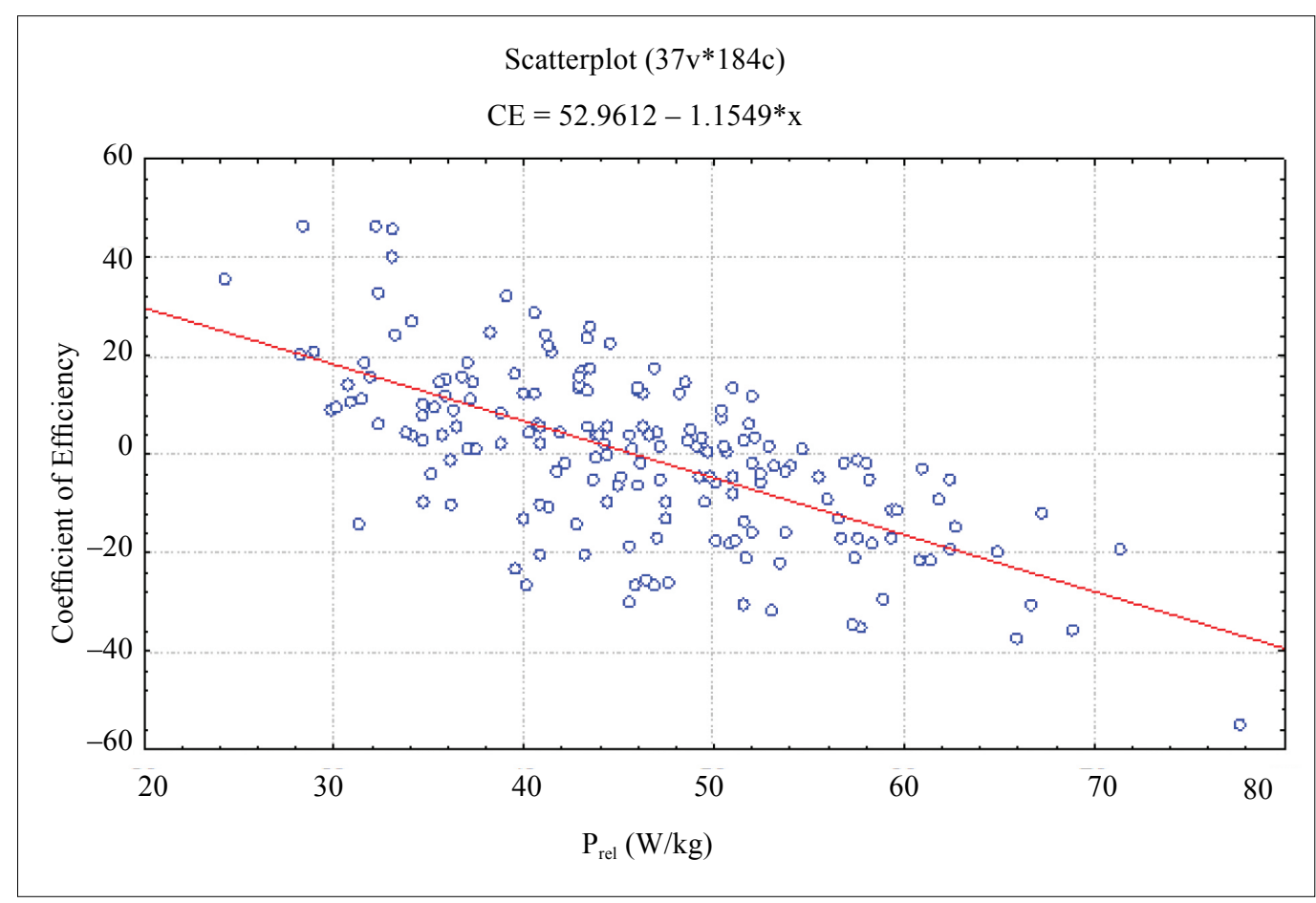

Figure 4. The correlation field $(r=$ $-.65)$ and the regression equation between the maximum of the relative power and the coefficient of the efficiency of the techniques in the snatch in men $(n=$ 184) 


\section{DISCUSSION}

The advantage of the proposed method for evaluating the effectiveness of the athlete technique is that it can be used for the registration of the necessary parameters in the extreme conditions of sport competitions. The disadvantage is that the maximum power measured in the exercise, depends not only on the physical capabilities of athletes, but also on the technique of the exercise performance. Therefore, the assumption that the maximum power measured during the competition reflects the speedstrength potential of the athlete is not quite correct. Notwithstanding this, the proposed method for evaluating the effectiveness of techniques may be useful, particularly in practical terms. It is enough to measure maximum power and the result in the classic weightlifting exercises using the proposed method and from the correlation field (Figure 2) immediately evaluate the effectiveness of techniques for subsequent action - what should be paid more attention to - the improvement of sports techniques or the development of lacking physical characteristics. It should be noted, however, that sports result depends not only on speed and power capabilities and athlete techniques, but also on other factors not accounted for.

Wide application of the regression method to solve sports problems is restricted by several conditions (Lanka \& Shalmanov, 2004; Lanka et al., 2005; Lanka, Shalmanov \& Medvedjev, 2012; Шалманов, 2002). Firstly, in case the research does not involve a great number of individuals, the precision of the regression equation is not high. Secondly, variable marks that are included in regression equations, may in an intrinsic way mutually correlate and the signs of plus or minus that stand before the equation's members may not correspond to the real situation. Thirdly, the regression equities with two and more variables are difficult to be applied in practice due to data obtaining, as well as - the selection of the necessary information is becoming more and more difficult. Multifactor regression equities may be applied in practice only if the variables they contain mutually do not correlate, but they correlate closely with the dependent variable - sports performance (Шалманов, 2002). In this case the variables depict those various factors that the sports result depends on, they show the importance of the factors and their investment in sport result. In the event there is a mutual correlation between the variables that enter the regression equity, it means that they depict the influence of some common factor. In this case we speak about co-linearity of factors: the factors correlate mutually, as well as they correlate with the sports result, however, those factors may have no logical causes - coherence of consequences with the result (Lanka et al., 2005).

The regression residuals method can be used to work out technique's model-indices, as well as movements' statistic models (Lanka et al., 2012). The method allows evaluating the efficiency of athlete technique, comparing them, though it fails to provide answer to the question in general and in particular to what determines these differences. The usage of the regression remnant method becomes more useful in case it is applied alongside with the biomechanical analyses (Lanka, 2004; Lanka, 2007; Шалманов et al., 2013).

\section{CONCLUSIONS}

1. Indicators of absolute power developed during acceleration of the bar in the snatch, are the most informative in assessing the level of physical fitness of athletes and the prediction of sports results. At the same level of athlete technical mastery the increase of power by 50 watt will increase the result in the snatch per 1 $\mathrm{kg}$ on average.

2. The regression equation between the result in the snatch and the maximum absolute power in the final acceleration of the bar gives a possibility to evaluate the technique of the effectiveness of each athlete: if it is better or worse than the average one and to what extent. This analysis gave one more possibility - to compare the set up performance with the performance that the athlete, taking into account their level of physical conditioning (maximal power), they would achieve if they improved their technique.

3. Regularities of the change in kinematic and dynamic parameters of movement of the bar with the growth of sports results and the mean values of the indicators registered in the conditions of competition in highly qualified athletes can be used as model characteristics of technical and speed-strength fitness and serve as a guide in the preparation of the athletes of lower qualification. 


\section{REFERENCES}

Baumann, W., Gross, V., \& Quade, K. (1988). The snatch technique of world class weightlifters at the 1985 World Championships. International Journal of Sport Biomechanics, 4, 68-89.

Garhammer, J. (1991). A comparison of maximal power outputs between elite male and female weightlifters in competition. International Journal of Sport Biomechanics, 7, 3-11.

Gourgoulis, V., Aggelousis, N., \& Mavromatis, G. (2000). Three-dimensional kinematic analysis of the snatch of elite Greek weightlifters. Journal of Sports Science, 18, 643-652.

Isaka, T., Okada J., \& Funato K. (1996). Kinematic analysis of the barbell during the snatch movement of elite Asian weight lifters. Journal of Applied Biomechanics, 12, 508-516.

Lanka J. (2007). Biomechanics of javelin throwing. Riga: Elpa-2.

Lanka, J., Konrad, A., \& Shalmanov, A. (2005). Evaluation methodology for assessing the effectiveness of sports technique. In Proceedings of XXIII International Symposium on Biomechanics in Sports (pp. 202-206). China, Beijing.

Lanka J. (2004). Realization conditions of the kinematical mechanisms in javelin throwing. Scientific Proceedings of Riga Technical University "RTU”, 8(6), 224-331.
Lanka, J., \& Shalmanov, A. (2004). Evaluation methodology of technique quality in shot put. In Proceedings of the Congress European Society of Biomechanics (pp. 102-103). Netherland: Eindhoven University of Technology.

Lanka, J., Shalmanov, A. \& Medvedjev, V. (2012). Integrative approach to the study and evaluation of technical preparedness in sports biomechanics. LASE Journal of Sport Science, 3(1), 2-3.

Ланка, Я. Е., \& Шалманов, А. А. (1982). Биомеханика толкания ядра. Москва: ФиС.

Шалманов, А. А. (2002). Методологические основы изучения двигательных действий в спортивной биомеханике: дисс. д. пед. наук. Москва: ФиС.

Шалманов, А. А., \& Скотников, В. Ф. (2013). Биомеханический контроль технической и скоростносиловой подготовленности спортсменов в тяжёлой атлетике. Теория и практика физической. культуры, 2, 103-106.

Шалманов, А., Скотников, В., Ланка, Я. (2013). Оперативный и текущий биомеханический контроль в спорте (проблемы и пути решения). Наука в олимпийском спорте, 3, 65-73.

Шалманов, А. А., Скотников, В. Ф., \& Панин, А. В. (2012). Кинематика и динамика движения штанги у спортсменов высокой квалификации в условиях соревнований. Олимп, 2, 27-31. 